\title{
Competing Business Models, Value Creation and Appropriation in English Football
}

\author{
Peter McNamara, Simon I. Peck, Amir Sasson
}

This article integrates the business model concept with an understanding of industry recipes to show how competing business models can co-exist in a competitive market. Drawing on data from the English Premier League, we show that alternative models - based on the acquisition of talent on one dimension and the internal development of shared team experience on the other - lead to differing value creation and value capture outcomes. Drawing on the time series nature of our data, we also show that transitioning between business models can involve a decline in performance (which may be temporary), and draw some implications for managers faced with the challenge of changing their business models.

(c) 2011 Elsevier Ltd. All rights reserved.

\section{Introduction}

The central strategy problem for managers is relatively simple: how to formulate and implement strategies that create value for customers and capture profits for the firm. There are a multitude of possible resource and capability configurations a firm can choose to create value, but also many uncertainties that can prevent them from converting these configurations into products that create value for customers and thus profits for the firm. Industry recipes and business models are complementary concepts that can assist managers in understanding the range of resource and capability configurations and uncertainties they face in selecting a strategy with a realistic probability of generating value for customers and capturing profits for their firm.

The essence of an industry recipe, as espoused by Spender, is as "the shared knowledge base that those socialized into an industry take as familiar professional common sense" which can be used as aids in the management of strategic uncertainties (Spender, 1989: 63). A challenge in researching industry recipes is that the process by which an industry recipe is identified and the links between resource configuration options, value creation for customers and value capture for the firm is not only particular to the industry and firm, but also must be measured qualitatively to account for the unique perspectives of both managers and the industry. While in their broadest form recipes are shared, taken for granted understandings of the industry, in practice they are overlaid by the specific assumptions and practices of individual decision makers and firm contexts, thus moving the focus from general guidelines towards the challenge noted above. Teece (2010) notes that one of the key contributions of the business model approach is that it offers clear guidance as to "how a firm delivers value to customers and converts payment into profit" a point captured by Baden-Fuller and Morgan's (2010) business models definitions table in their overview of the contributions to this journal's Business Models Special Issue. In this article we outline the essential recipe that applies to English Premiership Football industry - which we term a 'talent-based recipe' - and use the business model approach to define four business model types based on two value creating resources and capabilities that are central to such industry recipes - the talent of the team's players and the shared team experience they accumulate.

While Teece (2010) argues that it is sufficient for a business model to focus on what resources and capabilities are associated with the creation and capture of value, this article is motivated by the problem that prior research in the talent war literature has told us little about the different resource and capability configurations of talent and accumulated shared team experience that can create both value for customers and capture profits for firms. Firms in the same industry differentiate themselves from each other, so not all will have the same strategy and associated business model, but it is important that they know what kinds of business model configurations are possible within an industry recipe, and more importantly whether and how firms can change between models. Must a firm choose a single business model, which cannot be changed afterwards, or can it evolve one successful business model configuration into another? The empirical question we seek to explore in this article is whether more than one stable business model configuration can exist within an industry. We consider the stability 
of a business model in terms of its ability to generate both value for the customer and adequate financial returns for the firm. If a firm's business model cannot generate value for its customers, the stability of that typology over time must be questionable - will they continue to support such a firm with their custom? Nor can it regarded as being stable over the long term if it cannot deliver a financial return for the firm relative to the industry benchmark.

Our research demonstrates that some resource and capability configurations of talent and accumulated shared team experience are associated with both success on the field of play (which we see as being akin to value creation for customers) and with higher financial performance relative to the industry for the firm (i.e., value capture). We find it is possible for firms to move between business models, but that doing so involves shifting via an uncertain transitional state business model - a 'valley of death' - where there is likely to be a precipitous decline in the profits captured by the firm. If the firm succeeds in managing these risks, then it can move onwards to another stable business model which is likely to increase value creation for its customers, but not increase profitability for the firm. We first offer an overview of the business model concept and then develop four business model typologies drawing on the 'talent-based' industry recipe, which we test using a decade of data recording the performance of English Premiership Football teams.

\section{Business models in talent - based industry recipes}

Telling the story of how a firm creates value for customers is a common theme in the business model literature (Magretta, 2002). Baden-Fuller and Morgan (2010) argue that business models are typically conceptualized in a number of ways: as " $a$ set of generic level descriptors of how a firm organizes itself to create and distribute value in a profitable manner" (p. 157), in essence a taxonomic description of kinds "defined bottom up" or "used to classify firms" (p. 161); as typologies or "types used to classify firms ... derived top down through conceptual and theoretical work" (p. 161); as model organisms, or real life exemplary cases to be studied and learnt from; and finally as recipes of best practice, which facilitate managers to experiment and reason about the impact of choices they may make and guides for action. Our article takes a typology approach to business models: based on a conceptual understanding of talent-based industry recipes, we identify the crucial dimensions of success in our case industry, from which we generate four business model typologies that - from a conceptual perspective - we could expect to be stable configurations.

In many settings - such as the movie industry, team-based sport, consulting and higher education - executing strategies involves deploying significant amounts of human, rather than physical, resources, and a common belief in such settings is that competitive success is secured by the firm that captures and retains the highest quality talent. Top talent, it is assumed, is more productive in resolving business problems and more attractive to customers than lesser talent (Chambers, Foulton, Handfield-Jones, Hankin and Michaels III, 1998). This belief leads to the development of so-called 'Wars for Talent' where firms compete for the most talented labour - striving to attract the best professors, movie actors or managers which are supposed to lead to superior performance. (The concept may have emerged from an article by the same name in which McKinsey researchers surveyed a large sample of executives from 77 major US firms on the challenges of attracting and retaining talent - Chambers et al., 1998).

Another key dimension of the 'talent-based' industry recipe is that competitive success is also a function of the development of firm specific knowledge. This is an internal process of building knowledge about the fit between different individual productive resources. Individuals slowly become more familiar with the skills of other members of their team through the repeated process of working together on shared tasks - developing what commonly known in the literature as 'shared team experience'. The familiarity between team members who have worked together frequently has been shown to result in improved competitive performance of teams in industries as varied as software services and professional sports (Huckman et al., 2009; Berman et al., 2002). The challenge for managers is to understand the impact of configurational choices in terms of the two key dimensions of this industry recipe - the mix of talent and the level of accumulated shared team experience both on value creation for customers and value capture/profitability for the firm.

This article seeks to make an empirical contribution to our understanding of business models. Taking the perspective of a business model as a conceptually derived typology, we follow the approach of Bonaccorsi, Giannangeli and Rossi (2006) in classifying all the firms (i. e., the 'clubs') in our chosen industry segment (English Premiership Football) into four business model typologies comprised of higher and lower dimensions of the underlying components of talent (whether acquired or developed through team-working and interaction) and assess which of these business models are associated with value creation and appropriation. In this way we connect the external and internal labour market logics (i.e., hiring talent from the open market or developing and integrating it within the firm) conceptually, exploring how each facilitates the process of value creation and poses challenges to financial value appropriation for firms, as well as exploring empirically the tensions between the drivers of value creation for customers and of value appropriation for firms that are embedded in business models. So our contribution to the business models literature is to study the concept empirically with respect to both value creation (in terms of performance for customers) and value appropriation (in terms of financial value appropriated by firms). Studies of business model narratives mostly examine the value creation side but omit the profitability test for how the firm creates such value (Magretta, 2002), while quantitative empirical studies (e.g., Zott and Amit, 2007, 2008) focus primarily on value appropriation. We extend this empirical business model literature tradition by using longitudinal cross-sectional analysis to test for associations between the components of business models typologies and both value creation and appropriation.

This journal's special issue on Business Models noted that there are two common perspectives of business models in the empirical literature - static and transformational. The former perspective - where we seek to make our main empirical 
contribution - involves building typologies or taxonomies and testing models' performance impacts, while the latter view explores the process through which firms change business models (see, e.g., Demil and Lecocq, 2010). While do not explore the process of business model transformation itself, our dataset does enable us to note the performance impacts (in both value creation and value capture terms) of firms that change from one business model typology to another, so we are able to analyse the phenomena that, whilst premiership football clubs (i.e., firms) that change business models mirror the value creation performance (in terms of points the team accumulated in a season) of those that have used the 'new' model constantly over more than a year, they generally underperform in terms of value appropriation (return on sales). So while change in business model typology may bring changes in performance over time, it is not without risks: transition is not instant from one stable business model typology to another.

We address these issues in the business model and talent war literatures by analysing value creation and appropriation using a panel of all the clubs which appeared in the English Premiership football league over a twelve year period. The market for this cultural industry is large, much of it driven by lucrative broadcasting rights: the European football market earned total revenues of $€ 16.3$ billion in 2010, of which the English Premier League's portion was approximately $€ 2.5$ billion, with an annual growth rate of around 5\% (compared to English nearly $€ 2$ billion for revenues and a $2 \%$ growth rate in 2004 .) The English Premier League continues to record higher revenues and profitability than any other football league in the world - in 2010, for example, its revenues were over three times greater than the next highest earner, the Germany Bundeslig (approx. $€ 800$ million - Jones, 2005, 2011). These revenues have brought massive changes in the nature of the game, leading, for example to great variations in the modes of club ownership, with the local benefactor or cooperative ownership structures of yesteryear being replaced by the stock market quoted company or the wealthy international owner willing to advance substantial sums to attract top resources. Particularly for the former, but even for the latter, the notion that the football club needs to be self-financing over the long term is an explicit goal - this study, based on an articulation of the business model in football, aims to show the tensions inherent in this goal.

The remainder of this article is organised as follows: first we explain the underlying dynamics of value creation and appropriation in our setting; second, we make an empirical examination of the effects of business models on value creation and appropriation; and third, we conclude with some implications for the business model literature and for management.

The conceptual underpinnings of the four business model typologies: business model interdependence and trade-offs

The core assumptions of a talent-based industry recipe include: that talent is a scarce resource; that the very best is becoming increasingly difficult to recruit and retain; and a global shortage of top talent is negatively impacting the ability of firms to create and appropriate superior value (Chambers et al., 1998). The essence of this perspective is captured by McKinsey group research into senior managers which reports that "'A players' - the best 20 percent or so - raise operational productivity, profits, and sales revenues much more than average performers do" (Axelrod, Handfield-Jones and Welsh, 2001), and concludes: "companies scoring in the top quintile of talent management practices outperform their industry's mean return to shareholders by a remarkable 22 percentage points ..." So a core value creation logic of this recipe's business models is that a firm that can win the 'talent war' and acquire and retain the best industry talent will be better at identifying and servicing its customers' needs, and thus create more value for them that its rivals - and, by extension, more value to be captured.

One key method to access high quality talent is to acquire it from rival firms on external labour markets. In our setting there is an active international labour market for the transfer of football players' contracts. Assuming that the labour market is even semi-efficient, then (on average) the higher the price paid for a player the higher is their anticipated productivity: so we can expect that firms' acquisition of top talent, as measured by players' transfer prices, should be related to higher value creation at the acquiring club, as measured by the total of points it accumulates over the entire season.

Whilst the acquisition of highly talented employees is associated with increased value creation, both the 'winners curse' and skill transfer and integration problems may hamper the appropriation of financial returns by firms. In essence the 'winners curse' refers to the likelihood that, in a competitive bidding situation, the club that 'wins the war' to sign a highly talented player will almost certainly have paid more than the productivity it will be able to extract from that 'asset', and that it is the selling club that appropriates positive financial value from the deal. For example, a meta-analysis of 93 empirical studies has found that post-acquisition performance of acquiring firms is negative both in terms of accounting and stock market returns (King et al., 2004).

In contrast, the creation of a collective mindset, where each team member comes to anticipate the actions of other team members, facilitates more efficient integration and coordination of individual players' talents, resulting in higher performance outcomes where tasks require a high degree of speed and interdependence (Weick and Roberts, 1993). Stability enables the creation of firm specific talent whereby team members come to understand the talents of each other, while their repeated interactions over time enable them to become quicker in reacting to unexpected events in a coordinated manner and more fluid in implementing group activities (Rico et al., 2008; Weick and Roberts, 1993). This collective mindset is not easily transferrable across teams or firms. Collective minds are unique, and an individual's experience in one team does not mean they will integrate efficiently into another. A player's performance should improve over time as they learn to integrate their talent into the specific context of their current team, but their familiarity with the skills of other team members may only develop slowly. Past studies have shown this familiarity to result in improved competitive results on the field of play in NBA basketball teams (Berman et al., 2002) and more recently in club football teams (Frank and Nuesch, 2010), but not for teams such as national football squads - whose structures limited their opportunities to share experience, (Ruigrok et al., 2011). 
But the frictions involved in the transfer of talent across organizational boundaries, and mangers' knowledge and capabilities in resource deployment, mean valuable human talent may be a source of value creation but not generate bidding wars by rival firms seeking to purchase this talent to generate value at other clubs. A talented individual's value in one organizational context may be less than in another: we argue their productivity is at least partially firm specific, since continuous interaction with other team members fosters a collective mind that increases its members' ability to predict the behaviour of their colleagues and thus the efficiency with which tasks are performed (Berman et al., 2002). And this continuous interaction increases the talented individual's firm specific knowledge about how to best integrate their talent with that of the team. Such familiarity mechanisms can allow clubs appropriate a larger portion of the value they create, while avoiding the expensive and friction-ridden bidding wars to capture talent which may not, in the end, generate either customer or firm value.

So we propose that firms face competing pressures when considering between resource configuration choices: to participate in bidding wars to acquire high market value talent in the external labour market or to develop players' talents within the organisation; to adopt a deliberate and purposeful policy towards creating firm-specific shared team experience, or take a less strategic approach to team integration. Figure 1 provides a two-by-two synthesis of these arguments, based on the dimensions of the external market value of talent and the development of accumulated shared team experience, resulting in four stable business models typologies within a talent-based industry recipe.

We argue that firms may choose amongst these four business model typologies according to their available resources, but must be mindful of the varying performance outcomes they can expect in terms of value creation for customers and value capture for the firm. We also show that competing business models can be employed in the same context - and that the sequential interdependencies and trade-offs in their underlying dimensions does not necessarily mean that only one of them will be able to yield a club value creation and appropriation advantages over its rivals: clubs that understand the underlying dynamics of these outcomes can choose another business model if they wish to strike a different balance between value creation and financial value appropriation.

Stable business model type 1

As argued above, both participating in the external market for talent and investing in developing accumulated shared team experience internally can impact both value creation and appropriation. Working anti-clockwise from the upper left quadrant of Figure 1 a club may chose a type 1 business model, involves investing only in lower (B class) player talent and also adopting what we might call an 'low shared team experience' policy towards building accumulated shared team experience resulting in what for shorthand we will call a 'B talent, inexperienced' model. Such clubs will tend to lack both the requisite individual talent and the collective experience to work effectively as cohesive units, so we can expect that:

\section{Business Model Typologies: Expected and Resulting Value Creation and Appropriation}

\section{External Market Value of Talent}

\begin{tabular}{|c|c|c|}
\hline & Low & High \\
\hline 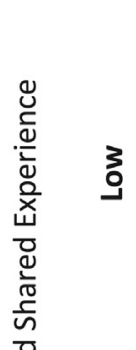 & $\begin{array}{l}\text { Business Model 1: } \\
\text { 'B' Team Talent } \\
\text { Low Shared Team Experience } \\
\text { Performance Expectations: } \\
\text { Theory } \\
\text { - Low value creation } \\
\text { Results: } \\
\text { Low value appropriation } \\
\text { - Low value creation } \\
\quad \text { Moderate value appropriation }\end{array}$ & $\begin{array}{l}\text { Business Model 4: } \\
\text { 'A' Team Talent } \\
\text { Low Shared Team Experience } \\
\text { Performance Expectations: } \\
\text { Theory } \\
\quad \text { Moderate value creation } \\
\text { Results: } \\
\text { Low value appropriation } \\
\text { - Moderate value creation } \\
\text { Very low value appropriation }\end{array}$ \\
\hline 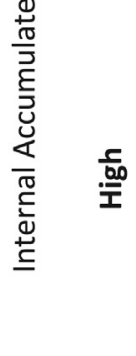 & $\begin{array}{l}\text { Business Model 2: } \\
\text { 'B' Team Talent } \\
\text { High Shared Team Experience } \\
\text { Performance Expectations: } \\
\text { Theory } \\
\quad \text { Moderate value creation } \\
\text { - High value appropriation } \\
\text { Results: } \\
\text { - Low value creation } \\
\text { High value appropriation }\end{array}$ & $\begin{array}{l}\text { Business Model 3: } \\
\text { 'A' Team Talent } \\
\text { High Shared Team Experience } \\
\text { Performance Expectations: } \\
\text { Theory } \\
-\quad \text { High value creation } \\
\text { - High value appropriation } \\
\text { Results: } \\
-\quad \text { High value creation } \\
\text { - High value appropriation }\end{array}$ \\
\hline
\end{tabular}

Figure 1. Business model typologies: expected and resulting value creation and appropriation 
Proposition 1: Clubs following a Type $1 \mathrm{~B}$ talent, low shared team experience business model will generate both low value creation, measured as points at the end of the season, and low value appropriation, measured as return on sales.

Stable business model type 2

Firms that decide not to participate in the war to buy in top-level player talent can nevertheless still choose to invest in developing a collective squad mindset, where team members learn to anticipate the actions of others, and thus integrate and coordinate their joint efforts more efficiently, in a 'B talent, experienced' model, as shown in the lower left quadrant. Greater mutual experience will result in the team working as more cohesive and effective on-field unit, compensating for lower individual talent levels, so that, generally:

Proposition 2: Clubs following a Type 2 B talent, high shared team experience business model will generate moderate value creation, measured as points at the end of the season, and high value appropriation, measured as return on sales.

The other two stable business models in this typology build on clubs making significant investments in external talent, which we assume will buy them players with top (A class) talent. These clubs can then choose to invest or not in developing the experience of their squad in terms of the accumulated shared team experience construct. This leads to our third and fourth business model types, as illustrated on the right side of Figure 1.

\section{Stable business model type 3}

Clubs that enjoy the combination of A-class talent and high levels of accumulated shared team experience (i.e., employing an 'A talent, experienced' business model - see lower right quadrant) ought to field powerful teams that perform very effectively and win often: such teams ought to be very attractive to customers, so we can expect A talent, experienced firms to be high in value creation. While the cost of acquiring such talent may be high, if the talent-based perspective is true, winning teams will attract more customers, who will pay more to watch their team, purchase more merchandise and yield additional revenue opportunities which ought to partially offset higher costs of acquiring talent, so that:

Proposition 3: Clubs following a Type 3 A talent, high shared team experience business model will generate high value creation, measured as points at the end of the season, and high value appropriation, measured as return on sales.

\section{Stable business model type 4}

Finally, we can expect that merely participating in talent wars without making the appropriate investment in the internal coordination of effort (as in the A talent, low shared team experience business model - upper right quadrant) will be detrimental to a club's situation. Players will lack sufficient shared experience and understanding of each other's capabilities to integrate into a cohesive team unit on the field, which only comes over time as they work together at the task of winning premiership football matches. To an extent, their individual talent ought to partially compensate for this lack of accumulated shared team experience, so we would expect A team, inexperienced business models to have moderate levels of value creation in terms of points gained at the end of a season. On the other hand, given its A-class talent, the club's supporters may well expect high levels of performance, and be disappointed when it is only moderate, reducing their satisfaction below their expectations, and with it their willingness to invest in the clubs merchandize or in other revenue generation opportunities. The costs of this business model will be high, as A class players must be purchased at open market prices, and given poorer results and thus lower revenues, we expect such this business model to offer very low value appropriation, so that:

Proposition 4: Clubs following a Type 4 A talent, low shared team experience business model will generate moderate value creation, measured as points at the end of the season, and low value appropriation, measured as return on sales.

Both these conceptual arguments and the expected results for each of these relationships are summarized in the Figure 1 two by two matrix, while our theoretical predictions for the four business models - in terms of both value creation and value appropriation for the club, which form the essence of the above propositions - can be summarised in an omnibus hypothesis:

Main Hypothesis: Alternative business model types will differ both in terms of value creation for customers and vale appropriation for the firms that adopt them.

However, clubs need not stick to one business model throughout their time in the Premiership, but can change to another with the aim of improving either value creation, value appropriation, or both. Our analysis will explore the performance impacts of both the static situation - where a club's business model remains constant - and the immediate performance impacts for club on changing their business model. Given that accumulated shared team experience is a time dependent concept, moving between business models has a sequential dimension.

Of particular importance (from this article's perspective) is firms that seek to pursue excellence through the A talent, experienced business model. Firms cannot acquire both talent and experience in the same year - while A-class talent may be purchased on the open market, such players will need more than a season of games playing together to develop above average levels of accumulated shared team experience. A number of clubs that have invested heavily in purchasing high-talent players have been criticized for delivering worse than expected performances on the pitch in the following season, as well as catastrophic financial results. Prima facie, therefore this investment strategy seems flawed - but it is the only path that exists 
for clubs which choose to move towards the A team talent/high shared team experience business model discussed above. Low payoffs from a club's investment in talent wars can only be recouped if it also invests in internally developing the experience of its squad. Hence, a sequential interdependency exists between the two A-class talent business models - clubs aiming for the high shared team experience version must journey there via the low shared team experience version.

In essence we advance the idea that firms in this industry literally play 'different games'. Guided by their understanding of the processes of value creation and appropriation, clubs adopt contrasting business models that address talent acquisition and accumulation of team experience differently. They develop strategies around the development and exploitation of different levels of talented resources and their understanding of the impact of such resources on value creation and appropriation. Hence, clubs that choose different business models are likely to experience different results in terms of value creation and appropriation.

\section{Industry overview and methodology}

\section{Industry background}

The English Premier league consists of 20 clubs: which play each other twice each season in games where winners gain 3 points, losers 0 and drawn games give each 1 point. The League exhibits the typical signs of an extremely competitive industry coupled with a dynamic market for player and managerial 'talent', albeit one that is regulated to an extent: clubs can only hire new players from rivals between seasons, or during a short mid-season 'transfer' window, although there is no cap on salaries players or managers can be paid. High turnover of players - and especially of managers - indicate the intensity of the talent war being fought between English Premier clubs (as it is indeed between football clubs globally), the ferocity of which results from how a club's end-of-season League ranking directly affects its following year's revenue stream. Specifically, teams finishing in the top four league places gain entry into the financially lucrative European club football championships for the next season, whilst the three lowest ranked teams are relegated to the lower division ('the Championship'). In 2004 figures, promotion to the Premier League could gain a club increased revenues of $£ 35$ million - but relegation from it resulted in a decline around $£ 13$ million (Jones, 2005). In 2006, the average Premiership club’s operating profit was $£ 10$ million, while the average Championship club recorded a loss of $£ 2$ million (Jones, 2007). By 2011 the cost of relegation from the Premiership had increased to an estimated $£ 25$ million in the first year, rising to an annual decline of $£ 41$ million if the club failed to win promotion back to the Premiership within the next four years (Switzer, 2011).

This context is a particularly valuable one in which to test our business models framework. First, the English Football Premiership is considered to be one of the most competitive professional football leagues globally, and hires talent from all over the world, thus making it an attractive industry to study business model typologies within a talent-based industry recipe. Second, extremely detailed and complete information is available of the major resources deployed in this setting demographic data on all club managers and professional football players in the league, including career histories and movement of players between teams, as well as team financial information is available for study. Table 1 describes the measurement of all our variables in detail.

Figure 2 shows the comparative levels of adoption of the four business model types described above by English Premiership clubs over the period 1993-2004 (its first twelve years of operation), as well as indicating the number that changed their business model in a given year. These configurations remained relatively constant over the period - most clubs appeared to employ a constant business model, and only a minority changing their business model in any given year. This suggests that moving between business model types is not a straightforward task, especially in the absence of significant ownership or managerial changes (a theme we return to below). Our omnibus hypothesis is that firms that employ different business models will differ both in terms of value creation and appropriation, and wee test the proposed relationships between each of the four business models and both value creation and value appropriation using two approaches: a comparison of means and a regression model. While our Figure 1 two by two matrix classifies four business models typologies according to team talent and shared team experience, Table 2 analyses the differences between them in terms of mean value creation (points at the end of the season). We report the mean performance of clubs that have used each business model for more than one year (which we label 'constant business models'), as well as those of clubs which changed to this business model type within the last year. Figure 3 gives a graphical representation of the relationship between value creation (points at the end of the season) and each of the four business model types. The comparable results for mean value appropriation (return on sales) for each of the four business models is reported in Table 3, and graphically represented in Figure 4 . The performance effects of business models and percentage change in business model components, controlling for clubs promoted from the lower Championship to the Premier League in a given year, is reported in regression models in Table 4.

The global finding from these tables and regression models is that different business models do have different impacts on both value creation and value appropriation, and that changing business models does have performance effects. The predicted relationships summarized in Figure 1 are broadly supported for each of the four business model types.

\section{Value creation results}

Figure 3 shows that the B talent, inexperienced business model is (as expected) associated with low value creation (points in a season), but that the B talent, experienced business model also records low value creation, as opposed to the moderate 
Table 1

Construct measurement

\begin{tabular}{ll}
\hline Construct & Measure \\
\hline $\begin{array}{l}\text { Value Creation } \\
\text { 1. Points }\end{array}$ & $\begin{array}{l}\text { The primary task of a football team is to win games. The team that has gained the most points at the end of the season is, } \\
\text { by definition, the one that has created the most value in terms best executing its assigned task. The more points a team } \\
\text { obtains, the higher their ranking in the league and therefore the higher proportion of broadcasting revenues, which } \\
\text { represent } 39 \% \text { of industry revenue (Jones, 2008), that the club receives. We therefore measured value creation as the } \\
\text { number of Premiership League points a club had gained at the end of each season. }\end{array}$
\end{tabular}

Value Appropriation

2. Return on Sales

et al., 2008).

Player Talent (Used to determine if a club is using a player talent-class 'A' or 'B' Business Model)

3. Players Value $(£)$

Our dataset consists of career histories of all players and football managers over the period 1993 to 2004 , which was used to estimate the mobile component of the talent war. Mobile player talent is measured as the publically available price paid by one club to another for any player that was employed by a rival club at the time of being hired. This value data is then aggregated for all team members to create an average player value. We construct high and low talent market values by splitting this series at its median value.

Firm Specific Talent (Used to determine if the team is an 'Inexperienced' or 'Experienced' Business Model)

4. Shared Team Experience Berman et al (2002) argue that a proxy measure for firm specific knowledge, or the collective mind's knowledge and efficiency, is the amount of shared team experience that players have. Shared team experience measures the average of the number of actual playing minutes players in the team have played with each other. It is assumed in this measure that to exploit their individual talent players need to learn how to integrate their skills into the wider team mind and that this is a cumulative process, so that the more a team has played together in the past, the better it may play in the future. The variable is calculated by summing the number of competitive game minutes that all players in the squad have ever played for this premiership team divided by the number of players in the squad. We construct high and low shared team experience values by splitting this series at its median value.

Business Model Typologies: B Players, Inexperienced B Players, Experienced A Players, Inexperienced A Players, Experienced Promoted to premiership Teams that for the premiership league of teams are:

Below median player value and below median shared team experience Below median player value and above median shared team experience Above median player value and below median shared team experience Above median player value and above median shared team experience Dummy variable $=1$ if a club was promoted from the lower league ('the Championship') in that year.

Data Sources: Player demographic data, player market value and points for each club at the end of the season were provided by AFS Enterprises www.11v11. co.uk. Accounting data was obtained from the Fame Financial database.

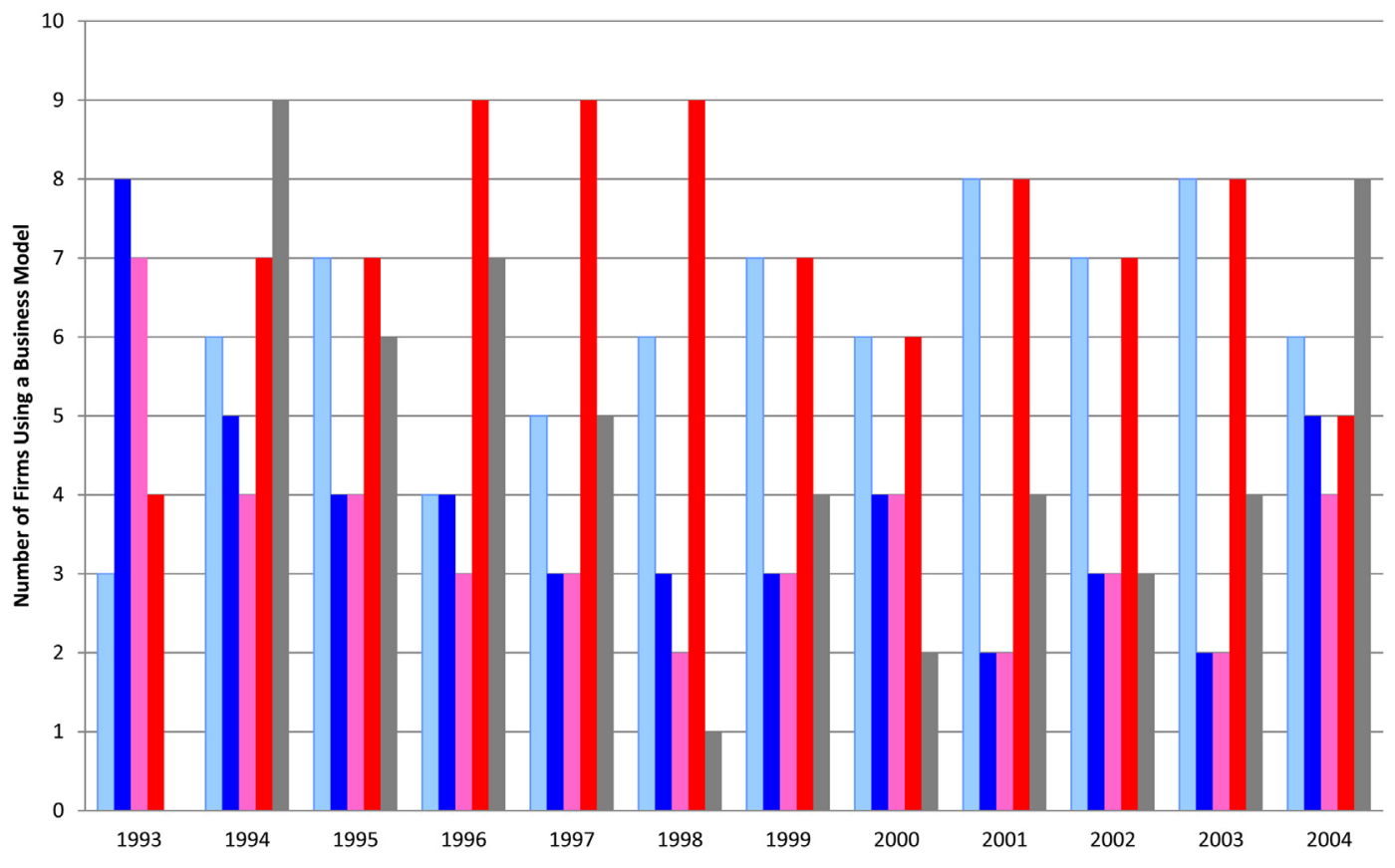

$\square$ B Talent, Inexperienced $\square$ B Talent, Experienced $₫$ A Talent, Inexperienced $\square$ A Talent, Experienced $\square$ Changed Business Model this year

Figure 2. Business models used by english premiership teams and business model change, 1993-2004 
Table 2

Value creation for business model types: league points in season

\begin{tabular}{|c|c|c|c|c|c|}
\hline Business Model & $\begin{array}{l}\text { Mean } \\
\text { Points }\end{array}$ & Std Error & $\begin{array}{l}\text { B Players, inexperienced } \\
\text { difference of means }{ }^{a}\end{array}$ & $\begin{array}{l}\text { B Players, Experienced } \\
\text { difference }^{a}\end{array}$ & $\begin{array}{l}\text { A Players, inexperienced } \\
\text { difference }^{a}\end{array}$ \\
\hline \multicolumn{6}{|l|}{ B Players, inexperienced } \\
\hline Constant Business Model $(n=40)$ & 45.9 & 1.59 & & & \\
\hline Changed BM this year ${ }^{\mathrm{b}}(\mathrm{n}=10)$ & 50.5 & 12.53 & & & \\
\hline \multicolumn{6}{|l|}{ B Players, experienced } \\
\hline Constant Business Model $(\mathrm{n}=32)$ & 47.3 & 1.68 & -1.35 & & \\
\hline Changed BM this year $^{\mathrm{b}}(\mathrm{n}=14)$ & 46.2 & 7.74 & 4.28 & & \\
\hline \multicolumn{6}{|l|}{ A Players, Inexperienced } \\
\hline Constant Business Model $(\mathrm{n}=22)$ & 54.6 & 2.53 & $-8.74^{\dagger}$ & -7.39 & \\
\hline Changed BM this year $^{\mathrm{b}}(\mathrm{n}=15)$ & 55.0 & 13.14 & -4.50 & -8.78 & \\
\hline \multicolumn{6}{|l|}{ A Players, Experienced } \\
\hline Constant Business Model $(\mathrm{n}=72)$ & 62.6 & 1.59 & $-16.74^{* * *}$ & $-15.39 * * *$ & $-8.00^{\dagger}$ \\
\hline Changed BM this year $^{\mathrm{b}}(\mathrm{n}=14)$ & 65.6 & 15.26 & $-15.35^{\dagger}$ & $-19.64^{* * *}$ & -10.86 \\
\hline
\end{tabular}

${ }^{*} p<.05, * * p<.01, * * * p<.001,{ }^{\dagger} p<.10$.

a Significance assessed using 2-tailed t-test. Only clubs with more than one year in premiership are included in this analysis.

b As appropriate, significance is assessed using Bonferroni test which assumes equal variances, or the Games-Howell test, which does not assume balanced samples or equality of variance.

levels we expected. Again as expected, the A talent, inexperienced business model generated moderate levels of value creation, and the A talent, experienced business model generated the highest value creation levels. A challenge in statistically testing if the mean performance of these two business models differed significantly from each other was low sample size but Table 3 shows statistically significant value creation performance differences between the two. The A talent, experienced business model shows greater statistically significant performance than any of the other three: as expected, the A talent, inexperienced business model performs less well, but better than the B talent, inexperienced model. The B talent, experienced model is statistically indifferent from the B talent inexperienced model, whilst its value creation performance is statistically significantly lower than that of the A talent inexperienced model. We can see, again from Figure 3, that clubs that change their business model in a given year match (approximately) the value creation performance of those that had employed the same business model type for longer.

The regression model in Table 4 takes the basic business model B talent, inexperienced typology as the baseline and compares the performance of all other business models relative to it. Controlling for promoted firms, model 1 in Table 4 confirms that both A talent business models outperform the base line B talent, inexperienced model in terms of value creation. Promoted clubs perform poorly, as they are new to the league and thus lack shared team experience of premiership football. We can see from model 1 that increasing the level of either business model dimension - greater talent, or greater

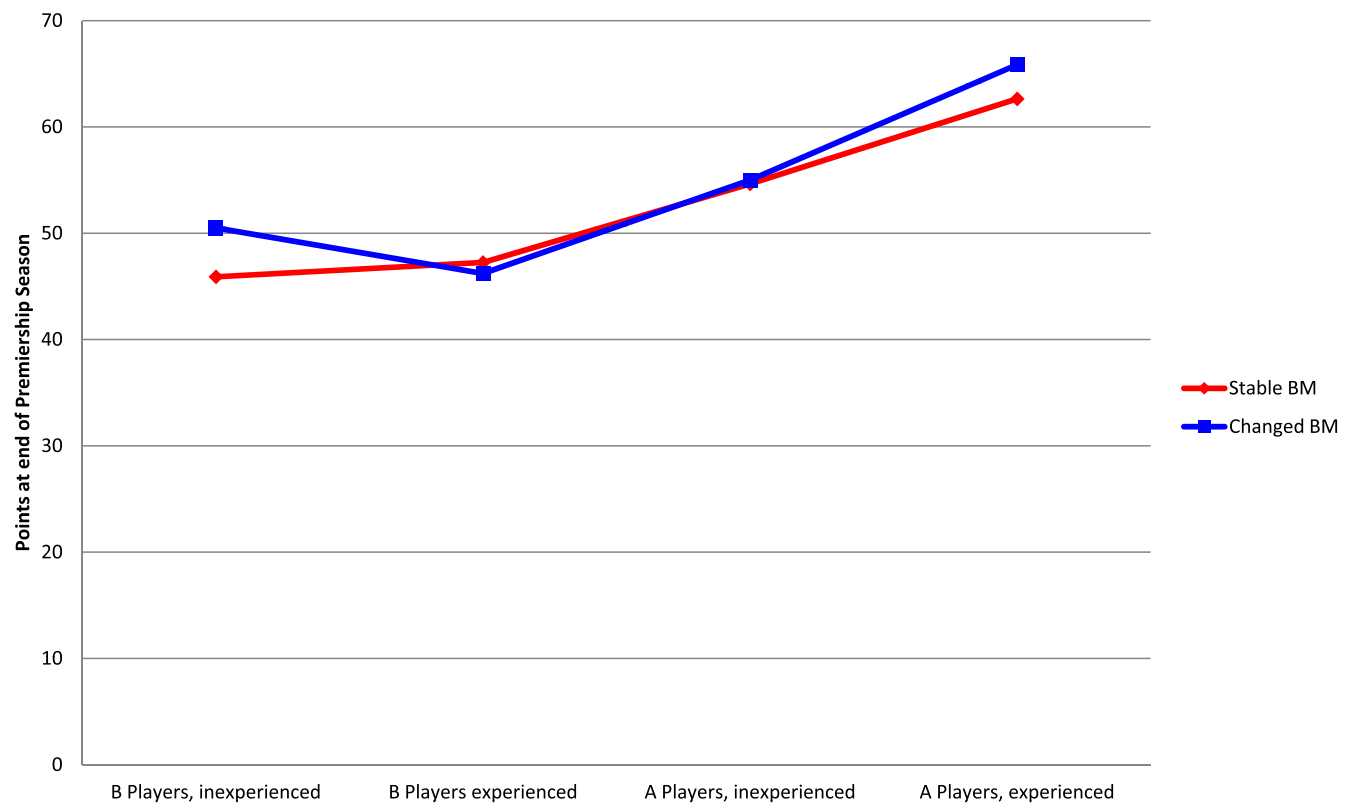

Figure 3. Value creation business models - points gained 
Table 3

Value appropriation for business model typologies: return on sales

\begin{tabular}{|c|c|c|c|c|c|}
\hline Business Model & $\begin{array}{l}\text { Mean Return } \\
\text { on Sales }\end{array}$ & Std Error & $\begin{array}{l}\text { B Players, inexperienced } \\
\text { difference of means }{ }^{a}\end{array}$ & $\begin{array}{l}\text { B Players, Experienced } \\
\text { difference }^{a}\end{array}$ & $\begin{array}{l}\text { A Players, inexperienced } \\
\text { difference }^{a}\end{array}$ \\
\hline \multicolumn{6}{|l|}{ B Players, inexperienced } \\
\hline Constant Business Model $(n=23)$ & -0.10 & 0.04 & & & \\
\hline Changed BM this year ${ }^{\mathrm{b}}(\mathrm{n}=3)$ & -0.12 & 0.08 & & & \\
\hline \multicolumn{6}{|l|}{ B Players, experienced } \\
\hline Constant Business Model $(\mathrm{n}=8)$ & -0.01 & 0.04 & -0.10 & & \\
\hline Changed BM this year ${ }^{\mathrm{b}}(\mathrm{n}=7)$ & -0.20 & 0.10 & & & \\
\hline \multicolumn{6}{|l|}{ A Players, Inexperienced } \\
\hline Constant Business Model $(\mathrm{n}=8)$ & -0.38 & 0.08 & $0.28^{*}$ & $0.37 * *$ & \\
\hline Changed BM this year ${ }^{\mathrm{b}}(\mathrm{n}=15)$ & -0.21 & 0.09 & & & \\
\hline \multicolumn{6}{|l|}{ A Players, Experienced } \\
\hline Constant Business Model $(n=43)$ & -0.02 & 0.03 & -0.08 & 0.01 & $-0.36^{* * *}$ \\
\hline Changed BM this year ${ }^{\mathrm{b}}(\mathrm{n}=7)$ & -0.19 & 0.19 & & & \\
\hline
\end{tabular}

$* p<.05, * * p<.01, * * * p<.001, * p<.10$.

a Significance assessed using 2-tailed t-test. Only clubs with more than one year in premiership are included in this analysis.

b As appropriate, significance is assessed using Bonferroni test which assumes equal variances, or the Games-Howell test, which does not assume balanced samples or equality of variance.

accumulated shared team experience - from the base-line model represents an upward business model trajectory associated with improved value creation. Taking the results of both the comparison of mean performance and the regression value creation model together, we can conclude that the expected performance relationships in terms of value creation expressed in Figure 1 (and in our propositions) - of an upward business model trajectory associated with improved performance - is supported with the exception of the B talent, experienced model, which, contrary to expectations, created only low rather than moderate value creation.

\section{Value appropriation results}

We can see from Figure 4 that clubs' value appropriation performance varies considerably depending on which of the four business model types they adopt, and also that those that change business model in a given year appear to underperform those which have been applying the business model for more than one year (with the exception of those who change to an $\mathrm{A}$ talent, inexperienced model). The value appropriation expectations summarised in Figure 1 are supported, with the exception

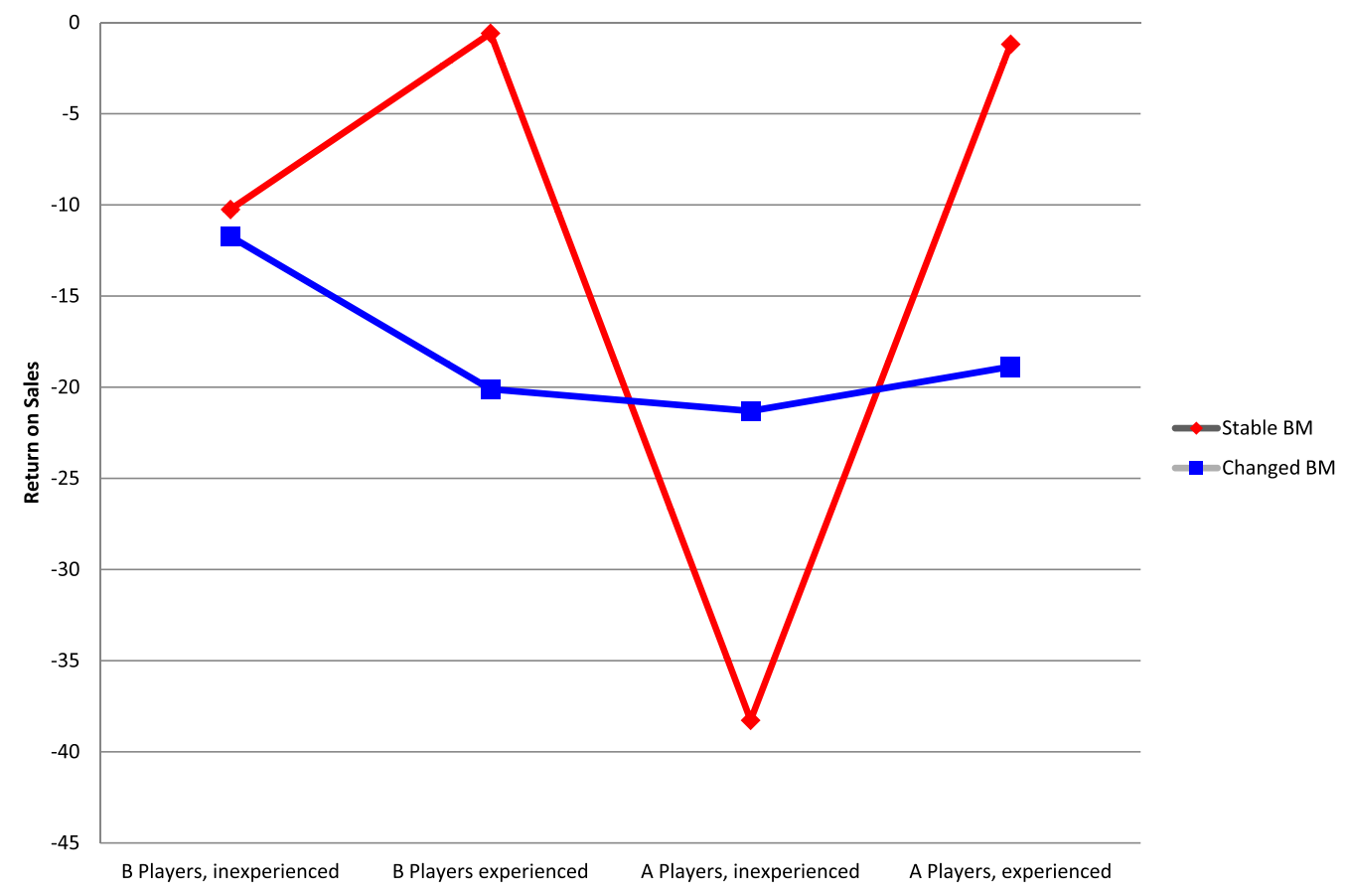

Figure 4. Value appropriation business models - return on sales 
Table 4

Talent war business model typologies - value creation (points) and appropriation (return on sales)

\begin{tabular}{lll}
\hline Business Model & Model 1 Points at End of Season & Model 2 Club Return on Sales \\
\hline B Players, Experienced & 1.300 & -0.067 \\
A Players, Inexperienced & $9.816^{* *}$ & $-0.281^{* *}$ \\
A Players, Experienced & $17.423^{* *}$ & -0.020 \\
Percentage Change in Player Value & $3.348^{*}$ & 0.018 \\
Percentage Change in Experienced & $4.483^{*}$ & -0.071 \\
Promoted to Premiership this season & $-4.895^{*}$ \\
Constant & $44.329^{* *}$ \\
Adjusted R & 0.331 & 0.066 \\
F - value & $21.207^{* *}$ & 0.009 \\
\hline
\end{tabular}

${ }^{\text {a }}$ Sample size. $N=246$ for Points Model. $N=121$ for Return on Sales Model, as not all clubs are public limited companies, thus financial data is unavailable for some clubs, which are excluded from this part of the analysis. Variables are averages based upon all data for all players in a team over each year from $1993-$ 2004.

${ }^{\mathrm{b}}$ Significance: $\& p<0.10 * p<0.05 * * p<0.01$.

${ }^{c}$ The baseline for these models is the B players, Inexperienced business model, which was predicted to have the lowest performance from our conceptual framework. The figures illustrate that this business model has the lowest points, but a moderate level of return on sales.

of the baseline (B talent, inexperienced) model, which was expected to record low value creation but in fact generated moderate returns on sales. As not all clubs are public entities with published financial data, the sample size is smaller for these models, so statistically significant relationships are more difficult to observe. The Table 3 results confirm that business models' mean value appropriation performances differ from each other, supporting our omnibus hypothesis. The performance of the A talent, inexperienced is lower than all the other three business models. Although we had insufficient data to test the significance of the value appropriation performance of clubs that changed business models in a given year, we were able to note that a club wishing to improve its value creation performance by moving to the highest performing (A talent, experienced) business model had to pass through the A player, inexperienced business model, which resulted (on average) in them experiencing the lowest value appropriation of any business model. To transform the club, the newly acquired A talent will need also to acquire accumulated shared team experience - if the club succeeds, we suggest it will go on to achieve both high value creation and value appropriation. These value creation results are also tested in Model 2 in Table 4 (again with the B talent, inexperience business model as the baseline), confirming that the A talent, inexperienced model underperforms all other models in terms of value appropriation - but also showing that change in either business model dimension (talent or accumulated shared team experience) has no immediate impact on a club's value appropriation performance.

\section{Discussion and contribution to business models literature}

This article seeks to fill a gap in the literature's conceptual understanding of business models by developing four stable business model types based upon the key dimensions of a talent-based industry recipe - team talent and accumulated shared team experience. Our conceptual model predicted four stable business model configurations, and our analysis supported the idea that more than one stable business model configuration is possible within an industry, although not all four models were found to be as stable as predicted by theory. We can see that maintaining high levels of accumulated shared team experience translates into the best financial performance for firms in this industry with differing levels of talent. If a club's owners are not concerned about its team's on-field performance (or value creation for the customer) then a squad of experienced B-class players generates as good a financial return as a team of experienced A-class players - but if they care about both types of performance, the A players, experienced business model type gives highest outcomes.

A challenge for talent-based industry recipes is that it is not possible in the long term for a club always to be able to maintain high levels of both talent and experience - as new players replace ageing team members shared team experience will inevitably suffer a temporary decline. Thus, on reflection, the two inexperienced business models can be considered as transitional states between two stable business models, which deliver higher financial returns (though not always higher value creation in the form of league points). Movement between inexperienced and experienced business models is a strategic choice for club management, involving navigating the performance decline - or 'valley of death' - of the A talent inexperienced business model. (The same temporary decline in shared team experience and performance dip is like to accompany replacing aging with young talent.) So a key uncertainty in this talent-based industry recipe appears to be the transition between different states of accumulated shared team experience, with the insecurity about whether or not the club can return to a stable A or B talent experienced business model. There is a clear risk that such transitions might result in a precipitous decline, either in value creation for customers (on-field performance - see Figure 3), or value appropriation for the firm (as in Figure 4). We can see that the uncertainty is greatest in value appropriation considerations, as all clubs moving away from an experienced business model will suffer substantial declines in value appropriation (see again Figure 4). Transitioning from B talent, experienced to B talent, inexperienced has limited impact upon value creation (as per Figure 3) and the negative impact of such a transition on value appropriation is also less than when the club makes the strategic choice to transition from the stable B talent, experienced business model to an A talent, experienced business model. The firm will need to buy in new talent, temporarily driving down experience, for the uncertain long term benefit of both high value 
creation and value capture. Until the new squad gains mutual playing experience, the club must pass through the costly transitional state of the A talent, inexperienced model, where the costs of its investments have not yet produced gains in either value creation or appropriation - so which can really seem like a 'valley of death'.

Our results show empirically that multiple stable business models can co-exist within a talent-based industry recipe, and that the choice of any specific business model does not lead to superior value creation and appropriation simultaneously. The different drivers of alternative business models result in trade-offs between strategies that can increase either - and (as noted earlier) some business models may be sequentially interdependent. By focusing on value creation narratives and subjecting them to a profit test we have demonstrated that the business models concept has a utility beyond the traditional - industry transformation - context of this literature. Furthermore, we demonstrate that combining the business model perspective with the notion of industry recipes provides a practical method by which the value creation and appropriation implications of major industry recipe dimensions can be explored. Understanding the underlying business model mechanisms of value creation and appropriation can lead to a range of profitable outcomes for firms that can use such knowledge to develop their business strategies.

An unexpected result of this analysis was that the B talent business models resulted in higher value appropriation irrespective of the level of internal experience. B talent business models firms incur much lower talent acquisition costs than do A talent business models, which can result in earlier profitability. However, such clubs risk being relegated to the largely unprofitable Championship league resulting in long term unprofitability. The club adopting the A talent, high shared team experience business model faces the twin challenges of integrating talent internally and the risk of value destruction from hiring stars through external labour markets. Stars ought to raise performance (in terms of on-field performance translating into increased revenues) over and above the cost of their contracts: but, of course, there is a risk that this may not occur. However, if such clubs survive the transitional business model (the 'valley of death') then the potential reward is high task performance and moderate value appropriation, with the opportunity of winning entry to lucrative European football competitions. Hence, in selecting a talent-based business model, club managements need to be mindful of the risks and rewards of each generic business model and be realistic in appraising their abilities to manage the individual components of each business model to achieve the desired levels of competitive task performance and financial performance. The relatively low amount of movement we noted between the various generic models also highlights the challenges for firms in this environment. Competing for the highest talent in the external labour market is likely to require a significant change in the club's financial resources: in the absence of some significant structural changes (e.g. in ownership) playing this game may be problematic. The recent history of Manchester City F. C. is instructive here: the club was purchased by the Abu Dhabi United Group in January 2009 and has since taken spending on talent to unprecedented levels (over £100 million during Summer 2009 alone) to compete effectively in the market for A class talent. And, although we demonstrate the role and the importance of developing accumulated shared team experience as key to value appropriation, the competitive pressures associated with league success mean that the player and managerial stability required can be difficult to achieve. Even the most successful manager in Premier League history to date - Manchester United's Sir Alex Ferguson - was famously just one game away from being dismissed (in the 1990 season) after two years at the club (Ferguson, 1999) - but he avoided the sack and the stability provided by his managerial longevity has since allowed for the successful development of younger players and integration of them and more established stars into successive Manchester United squads.

To this end, we have clearly elucidated the building blocks of both a talent-based industry recipe - talent and accumulated shared team experience - and of its associated business models, by understanding the drivers of value creation for customers and value appropriation for clubs. Combining these concepts brings new insights to considerations of talent-based industry recipes. We have demonstrated - both conceptually and empirically - that there are issues beyond the traditional assumption that acquisition of star talent is associated with improved task performance, and that this perspective is an oversimplification which can yield misleading implications for managerial practice. Our framework demonstrates that acquiring high quality talent from the external labour market is only associated with improved task performance where firm specific team experience is also developed. The important implication for both research and practice of these conceptual value creation models, in the context of their implementation within a talent-based industry recipe, is to make explicit the interplay between the external acquisition of talent and the internal development of team experience.

In summary, a key implication of this article is that the business model perspective facilitates clearer understanding of the process of value creation and appropriation in talent -based industry recipes, and that manager need to use this knowledge when deciding their firm's underlying business model. Our study's recognition that the acquisition of high potential talent is not a sufficient condition for value creation or value appropriation in this setting is important - a central strategic concern for Premier league clubs is the selection of a manager with expertise in both the realistic valuation of the talent available on the external market and the capabilities to manage the process of integrating that talent into the current team. A key role for such figures is to improve the productivity of such star payers in ways that are club-specific, which can help mitigate the danger that, once the external analyst community identifies a player as a star, a bidding war will start. If a player can be made more productive by one club rather than another - say due to its specific styles of play or management quality - then the player is more valuable to his current club rather than to a rival. If the management can be clear about this firm-specific productivity, rival clubs may be discouraged from bidding for that player, since his performance will inevitably decline if he moves.

Recent evidence from the football industry also offers a general warning to others competing in sectors where the value creation logic is based on the taken-for-granted assumptions of the talent-based industry recipe - that competition for Aclass talent is the key (if not the only valid) dimension. The profitability of the football industry has been falling since 2005 , 
while, at the same time wages (which represent $63 \%$ of its total revenue) have risen as 'cheap' capital - in the form of wealthy private investors - has entered the arena (Jones, 2008). Without a rational response to rising costs (for example, the increased costs of capital caused by the credit crunch) the talent war risks driving all clubs into long run losses, and makes the comments of the Arsenal F. C. chairman about focusing on a financially sustainable business model especially relevant:

I am pleased to report another year of satisfactory progress against our key objectives of delivering long-term stability and success through the operation of the Club as a business which is self-sustaining ... It was disappointing to see honours elude us last season, particularly by such a narrow margin ... however, we have every confidence in the playing squad and we are optimistic of prospects for 2008/09. Clearly, the level of competition both domestically and in Europe will once again be very high, but we are ambitious for success and keen to see the Club add to the seven major trophies it has so far won during Arsène Wenge's term as manager ... we have now reached the Group Stage of the UEFA Champions League for the 11th consecutive year - a record of which we are very proud (Arsenal Holdings PLC, Annual Report 2007/8, page 4).

Management is at the heart of both the industry recipe and business model concepts. The most strategic decision for shareholders is the selection of a management team they can trust to craft a rational value creation narrative and to continue to monitor, evaluate and report on whether or not the narrative is creating value and the extent to which such value is being appropriated by the firm. Where value is not being appropriated, shareholders in 'talent-based' industries must rely on management to initiate actions to restrain its negative impact before insolvency arrives. Evidence from the recent financial crisis - and the talent - wars that preceded it in sectors such as financial services - would suggest that professional football is not contextually unique. Conceptually, for the notion of industry recipes and business models to have currency, we add to the literature that advocates the need to focus on the value creation narrative and its transparent connection to firm profitability, as well as adding to our knowledge of how firms compete by bridging the general notions of their profit maximizing aspirations and their key strategic decisions.

\section{Acknowledgements}

We would like to thank the 3 reviewers and are particularly grateful to Professor Charles Baden-Fuller for valuable advice and guidance during the preparation of this manuscript. We also wish to thank the Professor Pat Gibbons for his support and guidance during this project, as well as those graduate students at UCD who assisted in data collection: Obinna Ezebuiro, David Guilfoyle, Eoin and Patrick Lynch, Alan O'Donovan and Adrian O'Mahony. We also thank participants at our session of the 2009 Academy of Management annual meeting. Player demographic and market value data for each club were obtained under licence from Association of Football Statisticians, www.11v11.com. Errors etc. remain our own.

\section{References}

Axelrod, E., Handfield-Jones, H., Welsh, T., 2001. War for talent, part two. The McKinsey Quarterly 2, 9-12.

Baden-Fuller, C., Morgan, M., 2010. Business models: practice and theory. Long range planning 43 (2/3), 156-171. Special Issue on Business Models.

Berman, S., Down, J., Hill, C., 2002. Tacit knowledge as a source of competitive advantage in the national basketball association. Academy of Management Journal 42 (1), 13-31.

Bonaccorsi, A., Giannangeli, S., Rossi, C., 2006. Entry strategies under competing standards: hybrid business models in the open source software industry. Management Science 52 (7), 1085-1098.

Chambers, E., Foulton, M., Handfield-Jones, H., Hankin, S., Michaels III, E., 1998. The war for talent. The McKinsey Quarterly 1, 44-57.

Combs, J.G., Crook, T.R., Shook, C.L., 2005. The dimensionality of organizational performance and its implications for strategic management research. In: Ketchen, D.J., Bergh, D.D. (Eds.), Research Methodology in Strategy and Management, vol. 2. Elsevier, San Diego, CA, pp. $259-286$.

Demil, B., Lecocq, X., 2010. Business model evolution: in search of dynamic consistency. Long Range Planning 43 (2/3), 227-246. Special Issue on Business Models.

Durand, R., Bruyaka, O., Mangematin, V., 2008. Do science and money go together? The case of the French biotech industry. Strategic Management Journal 29, $1281-1299$.

Ferguson, A., 1999. Managing My Life: My Autobiography. Hodder \& Stoughton.

Franck, E., Nuesch, S., 2010. The effect of talent disparity on team productivity in soccer. Journal of Economic Psychology 31, $218-229$.

Huckman, R., Staats, B., Upton, D., 2009. Team familiarity, role experience and performance: evidence from Indian Software Services. Management Science 55 (1), 85-100.

Jones, D., 2005. Annual Review of Football Finance 2004. Deloitte \& Touche LLP, Manchester.

Jones, D., 2007. Annual Review of Football Finance 2007. Deloitte \& Touche LLP, Manchester.

Jones, D., 2008. Annual Review of Football Finance 2008. Deloitte \& Touche LLP, Manchester.

Jones, D., 2011. Annual Review of Football Finance 2010. Deloitte \& Touche LLP, Manchester.

King, D., Dalton, D., Daily, C., Covin, J., 2004. Meta-analysis of post-acquisition performance: indications of unidentified moderators. Strategic Management Journal 25, 187-200.

Magretta, J., 2002. Why business models matter. Harvard Business Review 80 (5), 86-92.

Rico, R., Sanchez-Manzanares, M., Gil, F., Gibson, C., 2008. Team implicit coordination processes: a team knowledge-based approach. Academy of Management Review 33, 163-184.

Ruigrok, W., Greve, P., Engeler, M., 2011. International experiential diversity and performance at project organizations: the case of National Football Teams. Sport, Business and Management: An International Journal 1 (3).

Spender, J.C., 1989. Industry Recipes: An Enquiry into the Nature and Sources of Managerial Judgement. Basil Blackwell, Oxford.

Switzer, A., 2011. The cost of relegation from the premier league. The Telegraph, 23 May.

Teece, D., 2010. Business models, business strategy and innovation. Long Range Planning 43 (2/3), 172-194. Special Issue on Business Models.

Weick, K., Roberts, K., 1993. Collective mind in organizations: heedful interrelating on flight decks. Administrative Science Quarterly 38, 357-381.

Zott, C., Amit, R., 2007. Business model design and the performance of entrepreneurial firms. Organization Science 18 (2), $181-199$.

Zott, C., Amit, R., 2008. The fit between product market strategy and business model: implications for firm performance. Strategic Management Journal 29, 1-26. 


\section{Biographies}

Peter McNamara is a senior lecturer and academic director of the MSc Business at the Smurfit Graduate School of Business, UCD. The main themes of his research explore the relationship between project failure and success and firm performance; the antecedents and performance consequences of star talent; and the process of generating and sustaining cooperation in diverse stakeholder networks and his main empirical settings pharmaceuticals, sports and education. He has published in journals such as Research Policy, Journal of Business Venturing and British Journal of Management. UCD Smurfit Graduate School of Business, University College Dublin, Dublin, D4., Ireland. Tel: +353 1 7164733, fax: +353 17164762, e-mail: peter.mcnamara@ucd.ie

Simon I. Peck is an associate professor at the Weatherhead School of Management, Cleveland. His work examines the link between the actions and accountability of the company, characteristics of boards of directors and top management, and the firm's competitive advantage. Simon's work looks closely at topics of executive compensation contracts, board composition and structure, and how top executives do strategic planning. He has published in journals such as the Journal of Management Studies, Strategic Management Journal, Academy of Management Journal, Organization Science, and Academy of Management Perspectives. Weatherhead School of Management, Case Western Reserve University, Cleveland, Ohio 44106, USA. Tel: +1 216 3682030, e-mail: simon.peck@case. edu

Amir Sasson is an associate professor at the Norwegian School of Management, BI, having previously been a lecturer of management at the Smurfit School of Business at University College Dublin, Ireland and a visiting scholar at Stanford University. His research interests include mediation and mediators, value configurations, business models, network theory, cluster theory and finance. He is currently a co-organizer of the Israel Strategy Conference, and has published in journal such as Organization Science, Journal of Organizational Studies, and Strategic Organization. Department of Strategy and Policy, BI Norwegian School of Management, Nydalsveien 37, 0442 Oslo, Norway. Tel: +47 46410621, e-mail: amir.sasson@bi.no 